Cos

\title{
limiar
}

VOL.1 - $N^{\circ} 1-2^{\circ}$ SEMESTRE 2013

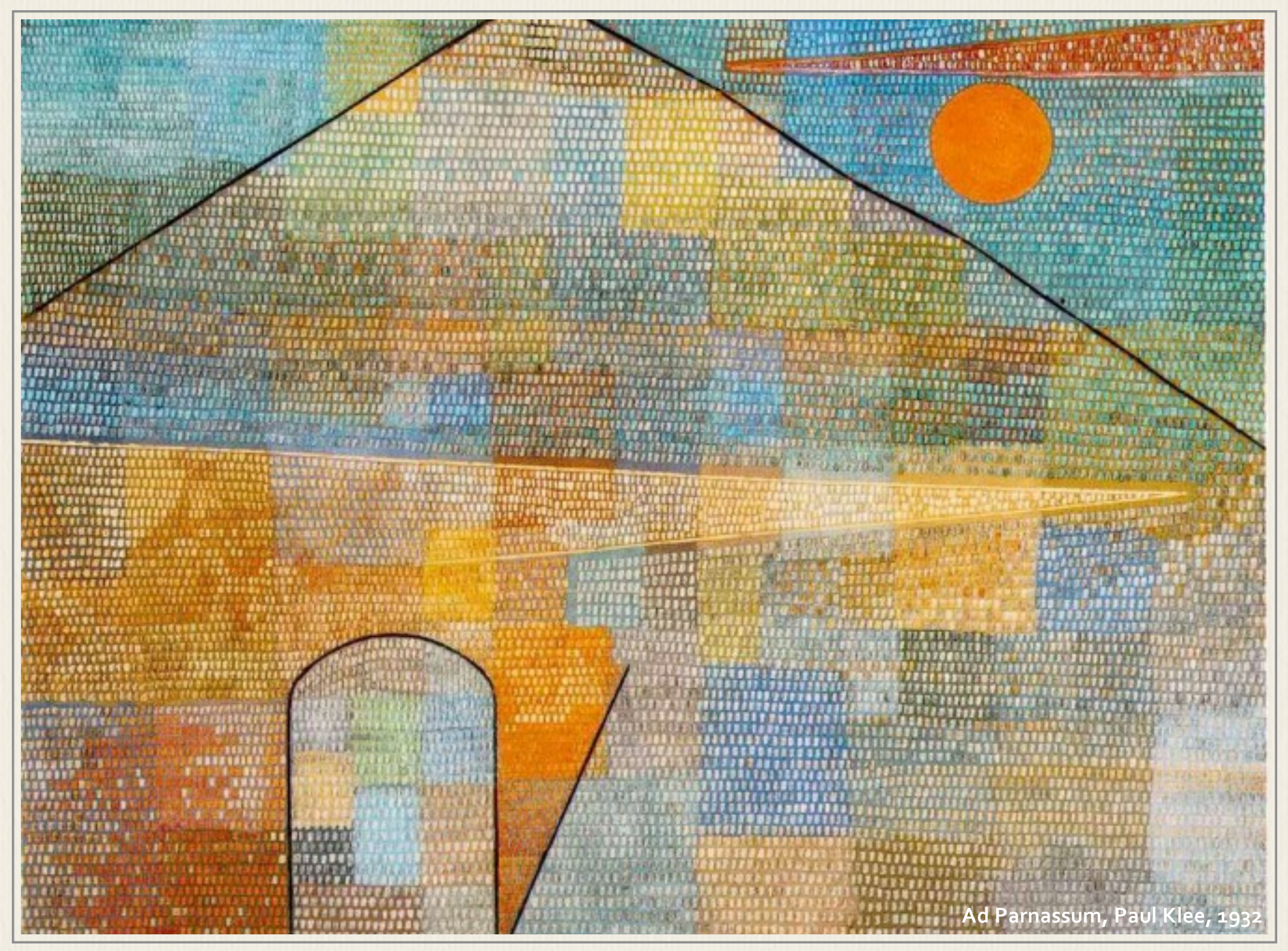




\section{Categorias epidíticas da ekphrasis}

João Adolfo Hansen

FFLCH|USP

1. O termo diégesis sugere a ideia de um percurso, sendo empregado para enunciados narrativos. Como a descrição de ações admite a estrutura temporal quando situa as coisas feitas no passado, a ekphrasis é necessária à prática do gênero histórico. Cf. Hermógenes. Progymnasmata.(Les Exercices Préparatoires). In $L^{\prime}$ Art Rhétorique. Trad. française intégrale, introduction et notes par Michel Patillon. Préface de Pierre Laurens. Paris, L' Âge d' Homme, 1997, p. 148.

2. A. Theon. Progymnasmata. Trad. Michel Pattilon. Paris, Belles Lettres, 1997, 118.6. A descrição é uma exposição da coisa por meio da opinião sobre a coisa; por isso a matéria dos progymnasmata são os textos antigos de poesia e prosa, como Homero e Demóstenes, considerados como autoridades donde se extraem elencos de opiniões verdadeiras sobre as coisas que a descrição imita.

3. "A ecfrase é um enunciado que apresenta em detalhe, como dizem os teóricos, que tem a vividez e que põe sob os olhos o que mostra". Cf. Hermógenes. Progymnasmata. (Les Exercices Préparatoires). In L' Art

Rhétorique. Trad. française intégrale, introduction et notes par Michel Patillon. Préface de Pierre Laurens. Paris, L' Âge d' Homme, 1997, 10-23
Nos progymnasmata, exercícios preparatórios de oratória escritos por retores gregos entre os séculos I e IV d.C., ekphrasis (de phrazô, "fazer entender", e $e k$, "até o fim") significa "exposição" ou "descrição", associando-se às técnicas de amplificação de tópicas narrativas, composição de etopéias e exercícios de qualificação de causas deliberativas, judiciais e epidíticas. Aélio Theon diz que ekphrasis é discurso periegético $-{ }^{1}$ que narra em torno - pondo sob os olhos com enargeia, "vividez", o que deve ser mostrado." Nos seus Progymnasmata, Hermógenes a define de maneira semelhante: técnica de produzir enunciados que têm enargeia, presentando a coisa quase como se o ouvido a visse em detalhe. ${ }^{3}$

O termo também nomeia um gênero de discurso epidítico feito como descrição de caracteres, paixões e obras de arte, esculturas e pinturas, praticado como exercício de eloqüência ou declamação (meletê) por filósofos e oradores da chamada "segunda sofística" do século II d.C., como Calístrato, Filóstrato de Lemnos, Luciano de Samósata, e aplicado por prosadores como Aquiles Tácio de Alexandria, Cáriton de Afrodísias, Longo etc., em proêmios de romances. No caso, a ekphrasis é definida como antigraphein ten graphein, contrafazer do pintado ou emulação verbal que compete com a pintura, descrevendo quadros inexistentes com enargeia.

A ekphrasis relaciona-se diretamente com passagens dos Tópicos $I$, da Retórica e da Poética, onde Aristóteles escreve sobre a atividade do historiador e do poeta, prescrevendo que devem compor imitando as opiniões tidas por verdadeiras pelos sábios ou pela maioria deles. As opiniões tidas por verdadeiras fornecem causas e explicações que tornam o discurso verossímil ou semelhante ao verdadeiro da opinião. A verossimilhança é uma relação de semelhança entre discursos e, na ekphrasis, decorre da relação da imagem fictícia da pintura que é descrita com discursos do costume antigo que fornecem causas e explicações do que é narrado sobre ela, tornando-o semelhante àquilo que se considera habitual e natural. A ekphrasis é falsa fictio, pois narra o que não é; sua audiência sabe disso e a ouve bem justamente porque a ouve como artifício cujos preceitos são críveis pois aptos para narrar o incrível. Como exercício de eloqüência, a ekphrasis é uma pragmática: evidencia justamente a habilidade do orador que espanta a audiência com a narração da falsa fictio tornando o efeito provável porque sua imaginação é alimentada pelos topoi da memória partilhada.

$\mathrm{Na}$ ekphrasis, o narrador se define como intérprete (exégetes) da interpretação que o pintor fez de sua matéria. Assim, geralmente antecipa a 
exposição das imagens fictícias com a declaração de que as viu diretamente ou que viu uma cópia delas. Esse "como se" é fundamental na ficcionalização da enargeia, sendo necessário observar que o autor finge transferir para a enunciação do narrador uma imagem pictórica com que compõe o enunciado como se efetivamente fizesse as passagens entre pintura e discurso indicadas por Filóstrato de Lemnos quando se autonomeia "hermeneuta", em seus Eikones, comentando sua prática como "exercício de eloquência". Desta maneira, o autor da ekphrasis inventa um narrador que amplifica um topos sobre o qual há concordância; por exemplo, o elogio do engenho, da perícia técnica de um pintor, do caráter extraordinário, da utilidade e da beleza de obra de arte. Depois de pequeno exórdio em que se apresenta, o narrador amplifica o topos, propondo descrever um quadro que atesta o engenho de um pintor. Por exemplo, Zêuxis, autor da pintura de uma família de centauros na ekphrasis "Zêuxis ou Antíoco", de Luciano de Samósata. Compondo a ekphrasis como um análogo do quadro, o narrador ordena a exposição em duas séries de argumentos especulares que descrevem aspectos pictóricos e os interpretam topicamente. Como disse, a imagem efetuada pela descrição é fictícia, mas compõe-se de topoi conhecidos da memória da audiência. Ativando-a, o narrador começa por expor a maneira como o pintor imitou topoi conhecidos para inventar imagens desconhecidas, estranhas ou maravilhosas, que associou a caracteres e paixões. Na ekphrasis "Zêuxis ou Antíoco", interpreta a interpretação que Zêuxis deu à família de centauros. Assim, a descrição remete o destinatário ao ato da invenção do quadro, reativando nele a memória dos topoi achados pelo pintor para interpretá-los. Por exemplo: descrevendo o corpo dos centauros, o narrador diz que os monstros têm crinas; ou que suas duas metades são peludas. Declarando que a crina do macho é "arrogante" e que as partes peludas demonstram "selvageria", atribui qualidades elocutivas à imagem descrita. Assim, as qualidades pictóricas da imagem traduzem ou evidenciam o éthos do monstro, "ferocidade", previsto pela memória de um mito ou poema. Interpretando sua descrição de imagens inexistentes, o narrador evidencia para sua audiência a memória dos topoi que a ekphrasis e a pintura aplicam à invenção da ficção, também evidenciando seu conhecimento da variedade dos preceitos técnicos que proporcionam as qualidades pictóricas das imagens segundo os graus do engenho do pintor e do seu engenho como orador. Achando a razão dos afetos figurados nas imagens efetuadas na ekphrasis nos casos de um mito, da história e da poesia, o narrador expõe a coisa por meio da opinião sobre a coisa, com autoridade, clareza e nitidez, presentando-a com enargeia. ${ }^{4} \mathrm{E}$ como a descrição da imagem e a interpretação dos seus topoi efetivamente não têm um primeiro, evidenciam-se para a audiência como efetuação artificiosa de um engenho perspicaz e versátil, merecedor de encômio, aplauso e fama.

Muitos textos desse gênero, principalmente os de Filóstrato e Luciano, foram retomados por autores como Alberti, Vasari, Blaise de Vigenères, Roger de Piles, que os imitaram ou prescreveram como matéria a ser imitada por pintores e escultores. ${ }^{5}$ No século XX, principalmente, historiadores da arte passaram a usar o termo restrito à acepção de "descrição de obra de arte". ${ }^{6}$ Esse uso praticamente apagou o significado técnico de ekphrasis como "exposição" ou "descrição" em geral. Assim, generalizando a acepção particular, vários autores afirmaram que o topos "clássico" da ekphrasis é o escudo de Aquiles, nos versos 483-608 do canto 18 da Ilíada. Trata-se efetivamente de "exposição" de aspectos, mas há duas objeções 
6. Pág. Ant.

Ruth Webb, Classics. King's

College.London

udlco70@bay.cc.kcl.ac.uk. Webb

afirma que essa leitura se acha em $P$

Friedlaender, Johannes von Gaza,

Paulus Silentiarius. Leipzig, 1912.

7. A descrição homérica do escudo foi emulada várias

vezes, como acontece nos

versos 626-731, do canto 8 da

Eneida, que descrevem o

escudo de Enéias. Os poetas

neotéricos latinos, que

emulam poetas alexandrinos,

compuseram ecfrases, como a

da colcha de uma cama do

poema 64, de Catulo. Também

Lucrécio, no De rerum

natura, 133-40, faz o retrato

de Marte e Vênus, afirmando

que imita uma pintura

helenística. E Ovídio, nas

Metamorfoses, 6, 70-128,

descreve os tapetes de

Minerva e Aracne. Também a

cena do pórtico de

Trimalquião, no Satyricon, de

Petrônio, é uma ecfrase de

gênero cômico.

8. W. J. T. Mitchell, "Ekphrasis and the Other". In Picture Theory. Chicago: The University of Chicago Press, 1994.

9. Cf., a propósito, Leon Kossovitch, "La descontinuité dans l'histoire de l'art". In Jean Galard (Org.). Ruptures: de la descontinuité dans la vie artistique. Paris: École Nationale Supérieure des Beaux-Arts/Musée du Louvre, 2002, p. 303-339. consideráveis à sua classificação como ekphrasis no sentido generalizado pelos historiadores da arte. A primeira é histórica e critica o anacronismo, pois o poema de Homero é muito anterior à prática do gênero e às retóricas que o doutrinam. A segunda é poética e, como fez Lessing no século XVIII, propõe que não se pode isolar a descrição do escudo da ação épica do poema. Como se sabe, Pátroclo é morto por Heitor, no canto 17; a cólera de Aquiles é imensa e sua mãe, Tétis, pede o escudo a Hefesto. Lessing afirmou que Homero não pinta o escudo como objeto autônomo ou terminado, mas como elemento descritivo que amplifica o epos da ação colérica do herói. ${ }^{7}$

Hoje, em tempos de desistoricização, o termo ekphrasis é usado para significar qualquer efeito visual. Da biologia à música, passando pela arqueologia, pela física, pela história literária, pela informática e por estudos culturais de gênero, o termo é usado fora dos seus usos retóricos antigos, significando "efeito sensorial", "visualização", "iconização", "espetacularização", "realidade virtual” e mais coisas. Interpretando seus usos na crítica de arte, Mitchell propôs que, na medida em que a história da arte é representação verbal da representação visual, a epkhrasis teria sido elevada a princípio disciplinar. ${ }^{8}$

Neste texto, passo ao lado dessas generalizações para especificar algumas categorias epidíticas da ekphrasis como "descrição", exemplificando-as com a prosopografia ou retrato de pessoa e procedimentos miméticos da "descrição de pintura" de proêmios de romances gregos antigos e textos de Luciano de Samósata e Filóstrato de Lemnos. Para fazê-lo, vou definir categorias e procedimentos da ekphrasis com exemplos de vários tempos, pressupondo a longa duração da instituição retórica até a segunda metade do século XVIII. Não utilizo as classificações dedutivas e fechadas das épocas e estilos, como "Antigüidade", "Idade Média", "Classicismo", "Barroco", pois são exteriores e implicam categorias anacrônicas. Suponho que é mais pertinente observar os processos de longa duração de transmissão de técnicas e modelos e das apropriações descontínuas deles. Com isso, pode-se demonstrar que autores situados em pontos diversos do tempo escolhem suas próprias amizades e inimizades artísticas e que, num mesmo período que nossas histórias literárias e histórias da arte classificam unitariamente com etiquetas dedutivas e evolutivas, como "Renascimento", "Maneirismo", "Barroco", encontramos efetivamente várias durações artísticas simultâneas e suas maneiras de conceber e produzir as artes e seus estilos, por vezes como um contínuo de emulações retrospectivas, por vezes como emulações descontínuas. ${ }^{9}$

Borges conta a história dos geógrafos de um rei que fazem um mapa do tamanho do país. É inútil, pois pretende ser a coisa. A fábula fornece uma pequena moral artística da ekphrasis: o efeito expositivo da técnica e do gênero não resulta de transposição de objetos empíricos, mas de processos da abstração compositiva do engenho do filósofo, orador, poeta e prosador que, competindo com pintores, estilizam particularidades de topoi pictóricos, históricos, oratórios e poéticos de autoridades antigas por meio de operações dialéticas e retóricas também quando fazem periégeses topográficas, que hoje aparecem à leitura como se tivessem sido diretamente copiadas da referência do discurso, como as descrições da Ática do Periegesis Hellados, de Pausânias.

Porque é mimética, a ekphrasis pressupõe os modos retóricos da imitação de topoi oratórios (endoxa) e poéticos (eikona). Os modos são aplicáveis em artes distintas, como a oratória, a poesia e a pintura, observando-se a continuidade ou 
10. No caso, faz-se distinção entre pintores e escritores, uma vez que uma pintura não é individualmente a mesma quando tem matéria diversa, isto é, outra tela e cores, merecendo mesmo algum louvor o pintor que, em seu artifício, copia outro. Ao contrário, no caso de escritores, a diversidade do papel e da tinta não impede que seja a mesma coisa o que se copia, uma vez que toda composição escrita recebe seu ser individual dos conceitos e das palavras de que é tecida, não da matéria do escritório.

11. Hermógenes, "Les Catégories Sylistiques du Discours". In op.cit. pp. 319419. homologia do procedimento mimético entre as artes e, simultaneamente, a competição delas. Assim, os objetos descritos nas ekphraseis de Luciano e Filóstrato não preexistem ao ato da invenção do discurso em que aparecem modelados segundo argumentos da invenção e preceitos elocutivos do gênero epidítico. Retoricamente, esse ato é orientado pela perspicácia do engenho do autor, caracterizado pela penetração da visão analítica do juízo que examina imitativamente a matéria particular a ser encenada, classificando-a na invenção segundo elencos de argumentos genéricos memorizados, topoi do gênero em que se exercita, e abstraindo emulatoriamente, de elencos de usos poéticos, oratórios e históricos desses argumentos consagrados como autoridades do gênero, os aspectos que caracterizam a matéria particular a ser tratada enquanto tal e não como outra. A emulação é a imitação da propriedade ou predicado que produz prazer numa obra determinada. O predicado é um gênero comum, que inclui espécies muito diversas de invenções possíveis. Depois que descobre o gênero, o autor aplica engenhosamente uma espécie semelhante à obra imitada quanto ao predicado, e que, pelo fato de ser apenas semelhante, é obviamente diferente. A diferença, tratada elocutivamente, deve fazer com que o predicado encontrado participe mais e melhor nela. Assim, o modo de produzir semelhanças e diferenças distingue a emulação da imitação servil. ${ }^{10}$

Ao mesmo tempo que acha os predicados a serem emulados, o engenho do autor é versátil e veloz, encontrando para cada particularidade da matéria com que preenche os topoi genéricos a palavra mais adequada. Na ekphrasis, a palavra é especificada segundo várias qualidades que se aplicam fazendo o discurso convergir para o efeito de enargeia ou evidentia: pura, clara, nítida, nobre, rude, veemente, brilhante, vigorosa, complicada, elegante, ingênua, picante, graciosa, sutil, agradável, vivaz - bela, enfim. ${ }^{11}$ Ao mimetizar propriedades da coisa (o topos ou a res retórica) segundo o endoxon - a opinião verdadeira que os sábios ou a maioria deles têm da coisa- o autor da ekphrasis sabe que seu público tem a memória da mesma opinião e que, julgando o efeito, observa se é análogo e proporcionado a ela, maravilhando-se com a probabilidade eficaz da beleza, mas também com a engenhosidade da invenção e a perícia elocutiva da arte que, com coisas e palavras conhecidas, produzem efeitos inesperados. Nenhum detalhe da ekphrasis é informal, expressivo ou realista, pois todos eles se incluem em uma invenção e elocução que aplicam preceitos previstos pela instituição retórica para transformar o ouvido do ouvinte, constituído na variação elocutiva do discurso, num olho incorporal que os avalia. Como na alegoria de Zêuxis, que abstrai particularidades perfeitas das virgens de Crotona para figurar Helena bela como Afrodite, a imagem da ekphrasis resulta da abstração detalhadora de particularidades da matéria que preenchem tópicas conhecidas numa elocução engenhosa e perita. Por isso mesmo, voltando a Borges, a descrição necessariamente sempre omite algo. Se não fosse assim, haveria dois Crátilos e não Crátilo e seu nome.

Com essa referência sumária ao artifício retórico, lembro que nossas histórias literárias e histórias da arte são caudatárias das estéticas produzidas no século XVIII. Elas constituem o tempo e a história como contínuo evolutivo, classificando os estilos artísticos por meio de unidades dedutivas, sucessivas e irreversíveis, "classicismo", "maneirismo", "barroco" etc. ${ }^{22}$ Aplicadas à ekphrasis - como técnica ("descrição") e gênero ("descrição de pintura") - as classificações dedutivas eliminam os preceitos retóricos que ordenam a invenção e a elocução do efeito,
12. Cf. Leon Kossovitch. "La descontinuité dans l'histoire de l'art ". In Jean Galard (Org.). Ruptures : de la descontinuité dans la vie artistique. Paris, École Nationale Supérieure des Beaux-Arts/Musée du Louvre, 2002, p. 303-339. 
interpretando-o anacronicamente em termos realistas e expressivos como representação de conteúdos de totalidades preformadas ao ato da sua invenção. Lida a ekphrasis como imitação da natureza, reflexo do chamado "contexto social" e expressão da psicologia dos autores, eliminam-se os preceitos retóricos do seu artifício epidítico, propondo-se que representa coisas empíricas e obras de arte que teriam efetivamente existido como modelos para seus autores. Com ironia, já se disse que a descrição periegética do escudo de Aquiles, no canto 18 da Ilíada, demonstra que a principal coisa demonstrada pelas leituras que a utilizam para fazer reconstituições arqueológicas é que não têm fundamento também na empiria que pressupõem e pretendem reconstituir, pois nenhum escudo poderia ser tão grande para conter todos os motivos descritos. O mesmo se pode dizer da crença de que as ekphraseis de Filóstrato ou Luciano testemunham a existência de obras perdidas. Esse entendimento as constitui como documentos de uma reconstituição que elimina justamente o que nelas é não a suposta realidade empírica de objetos supostamente vistos pelos autores, mas a realidade dos preceitos retóricos de um ver coletivamente partilhado e exposto segundo a verossimilhança e o decoro de seu gênero.

As mesmas tópicas epidíticas e as categorias elocutivas do gênero "descrição de pintura” podem ser imitadas descritivamente em gêneros diversos, como pragmatografia, descrição de coisas, como a colcha no poema 64, de Catulo, sobre as núpcias de Tétis e Peleu; prosopografia, descrição de pessoas; etopéia, descrição de paixões e caracteres, como na obra de Teofrasto, nas ekphraseis dos Filóstratos e Luciano, e, no século XVII, na obra de La Bruyère; como topografia, descrição de lugares reais; como topotesia, descrição de lugares imaginários, como os lugaresamenos da bucólica e as cenas das ekphraseis dos Filóstratos e Luciano; chronografia, descrição de tempo, como o das estações do ano etc.

Assim, como ler a descrição antiga fora do anacronismo dos quadros estéticos do idealismo alemão das histórias literárias e histórias da arte e da desistoricização pós-moderna?A ekphrasis é tabular, ou seja, condensa na particularidade da palavra ou do enunciado a simultaneidade mimética de procedimentos e efeitos que é preciso considerar para lê-la de modo não-anacrônico: a memória dos topoi que aplica; a adequação mimética da matéria tratada aos preceitos do gênero; a clareza, a nitidez e a vividez do léxico visualizante; a intensificação patética da enunciação e do destinatário; a presença de algo ausente inventado como anterior ao ato da descrição; a verossimilhança e o decoro específicos do gênero; a emulação de autoridades antigas; a erudição histórica, oratória e poética da memória; a competição entre artes consideradas "irmãs" etc. É útil pensar, com Hermógenes, que algumas categorias que regulam esses procedimentos existem por si mesmas; outras pressupõem procedimentos e categorias de segundo grau que as constituem; outras, ainda, têm uma ou várias partes em comum E, de maneira geral, umas categorias são classes incluindo espécies; e algumas apresentam uma diferença pela qual se associam e separam de outras. ${ }^{13}$ Por exemplo, na ekphrasis feita como discurso panegírico, que louva o engenho e a arte de pintores com exemplos e comparações, geralmente as várias espécies de registros elocutivos aplicados remetem o destinatário a preceitos e gêneros diversos que se evidenciam simultaneamente na visualização descritiva. Porque é mimética, a ekphrasis é tabular; assim, quando se tenta especificar a particularidade das categorias que constituem essas espécies elocutivas, cada ponto do discurso que as comenta é 
remetido simultaneamente ao geral dos preceitos miméticos paralelos que aparecem na particularidade delas como sua definição e regramento. Como se a simultaneidade da instituição comprimisse sua seqüência, o discurso é marcado com a repetição. A repetição é necessária, no entanto, e, aqui, desejada.

Hoje opomos descrição e narração, hierarquizando a descrição na posição subalterna de luxo analógico, quando a definimos como encadeamento metonímico ou somatória de aspectos justapostos sem relações de antecedente-conseqüente e causa-efeito. Nas nossas definições, a descrição cita discursivamente partes ou minúcias da superfície aparente da sua referência, o espaço, diversamente da narração, que dá conta de processos temporais de "antes-depois", sendo por isso preditiva, como dizia Barthes: se o personagem abre uma porta, algo se segue: ou sai ou entra ou age arbitrariamente ou a razão ainda se verá. Por outras palavras, a narração envolve escolhas, ações, conseqüências e, podendo figurar processos causais e temporais complexos, já foi considerada superior à descrição, como naquele texto velho em que Lukács retoma Lessing para desqualificar Flaubert como descritivo. No entanto, sabemos que as diferenças de descrição e narração não têm existência semiológica, como Genette demonstrou, pois são apenas diferenças semânticas, ou seja, dependentes do jogo de linguagem particular do discurso em que ocorrem. Lingüística e gramaticalmente, não há nenhuma diferença entre a narração das ações de Heitor e a descrição do escudo de Aquiles ou de qualquer outra coisa real ou fantástica, como o cabo Sunion ou um centauro. A diferença, no caso, não é lingüística ou gramatical, mas retórica e sempre relacionada ao gênero do discurso. Retoricamente, qualquer discurso implica a relação de pressuposição entre a pessoa e a situação em que age, ou o personagem e a cena onde atua; assim, tanto a descrição do caráter e paixões de pessoas e personagens quanto a do espaço subordinam-se homologamente aos preceitos do gênero, como se vê na "roda de Virgílio".

Nas retóricas antigas, essa relação de pressuposição implica que não se faça a oposição descrever/narrar. Retoricamente, quando se trata de processos, a descrição integra a narratio; e, principalmente, quando se trata de pessoa, personagem ou coisa implicados em processos, ela se aplica na invenção dos tipos e seus caracteres (éthe) e paixões (pathe), segundo os quatro graus do encômio doutrinados por Aristóteles e reiterados pelo anônimo da Retórica a Herênio, por Quintiliano e Menandro. Quintiliano- e, por exemplo, muito depois dele, Erasmofalam da narratio como rei factae aut ut factae utilis ad persuadendum expositio: exposição da coisa feita ou da coisa como feita útil para persuadir. A coisa feita- a ação particular, como a conquista da Gália, realizada por pessoa particular, como Júlio César, no gênero histórico, - e a coisa como feita - a ação universal, como a conquista do Lácio, realizada por personagem universal, como Enéias, no gênero épico - podem ser apenas citadas brevemente, nos casos em que já são conhecidas pelo auditório. Mas o preceito de que as res factae e seus exempla devem ser amplificados e ornados descritivamente está sempre presente nos modelos de dilatação narrativa dos exercícios que os latinos chamaram de opera minora, os progymnasmata gregos, principalmente nos exercícios epidíticos, em que a amplificação é principal. Um desses modelos propostos como exercício para desenvolvimento de habilidades técnicas do orador é a narratiuncula, ao pé da letra "narraçãozinha", amplificação descritiva usada pelos alunos latinos de oratória e, a partir do século XVI, pela Companhia de Jesus na educação de padres sermonistas. 
14. Miguel de Salinas. Rhetorica en lengua castellana. Alcalá de Henares, 1541, ff. XCVII. O louvor pressupõe as técnicas de descrição de pessoa e suas virtudes ou vícios; a particularização pressupõe o detalhamento descritivo de partes; a comparação pressupõe o estabelecimento de semelhanças e diferenças que também são descritas. Ainda no século XVI, Frei Luís de Granada, em seu Rhetorica ecclesiastica, expõe os modos de amplificação dos exemplos, expondo as figurae

sententiarum, as figuras das sentenças. A partir do final do século XV, os tratados gregos de Hermógenes, Dionísio de Halicarnasso, Demétrio de Falero, Longino, Aftônio etc.levados de Constantinopla para a Itália no século XV, passaram a ser lidos em cidades italianas, em Castela e na França. No fim do século XVI, os preceitos desses retores sobre o estilo sublime, sobre a enárgeia, a força e a abundância dos estilos foram opostos e muitas vezes misturados aos preceitos aristotélicos e horacianos da unidade do estilo, compondo o que hoje as histórias da literatura classificam como "barroco". É o que se observa na invenção de novos gêneros, como a tragicomédia de Guarini e Lope de Vega. Ou nas descrições sublimes de tópicas humildes da Fábula de Polifemo e Galatéia e das Soledades, de Góngora.
Da mesma maneira, as fábulas, com sua tipologia de animais alegóricos de virtudes e vícios que amplificam a ação principal narrada; ou a chria, menção breve de sentenças e coisas memoráveis, são consideradas elementos narrativos aplicados como descrição de coisas, eventos, pessoas e como detalhes caracteriais e morais de personagens etc.

Até a segunda metade do século XVIII, enquanto a instituição retórica teve vigência, a descrição integrou-se à narração como técnica amplificadora. No Tratado de los avisos em que consiste la brevedad y la abundancia, de 1541, Miguel de Salinas o evidencia, citando Erasmo e Quintiliano para propor três modos de acrescentar ou amplificar exemplos da narração diretamente relacionados com as técnicas descritivas da ekphrasis:

A primeira maneira de acrescentar os exemplos é louvando-os, e esse louvor se retira do autor que os escreveu ou da pessoa ou gente onde ocorreu ou da mesma coisa de que o exemplo trata(...) A segunda maneira de dilatar os exemplos será quando se põem com todas as suas particularidades, amplificando-as e encarecendo-as onde for adequado(...) A terceira maneira de dilatar os exemplos é por comparação, e é quando por alguma semelhança se mostra o exemplo que se traz ser semelhante ou dessemelhante, ou contrário, ou maior, ou menor, ou igual. ${ }^{14}$

Para ler a ekphrasis retoricamente, é útil observar que nos textos gregos o verbo graphein significa tanto escrever quanto pintar, assim como o substantivo graphé significa escrita e pintura. A equivalência de escrita e pintura no grego graphein permite propor não a identidade da poesia e da pintura, por exemplo, mas a homologia dos procedimentos miméticos aplicados a uma e outra. Assim, quando se lê uma ekphrasis como "descrição de pintura", deve-se antes de tudo observar que, na efetuação visualizadora da pintura ausente, efetivamente nada existe- em termos lingüísticos e gramaticais- de propriamente plástico ou pictórico. $\mathrm{O}$ significante e o significado de termos visualizantes como "vermelho" ou "redondo" não são, obviamente, vermelhos ou redondos. A ekphrasis é uma arte mimética e, para lê-la segundo o seu modo de operar antigo, devem-se considerar os modos retóricos prescritos para que o discurso mimetize em sua invenção e elocução os procedimentos miméticos considerados próprios da invenção e da elocução da pintura. Para isso, deve-se descartar a oposição romântica "forma/conteúdo", que a instituição retórica não conhece, e observar os preceitos epidíticos da ekphrasis. Leia-se a definição de Hermógenes:

A ekphrasis é um enunciado que apresenta em detalhe, como dizem os teóricos, que tem a vividez (enargeia) e que põe sob os olhos o que mostra. Têm-se descrições de pessoas, de ações, de situações, de lugares, de tempos e de muitas outras coisas. De pessoas, como em Homero ele era cambaio $e$ mancava de um pé (Ilíada, 2, 217); de ações, por exemplo a descrição de um combate em terra e de uma batalha naval; de situações , por exemplo a paz, a guerra; de lugares, por exemplo portos, rios, cidades; do tempo, por exemplo a primavera, o verão, uma festa (de data fixa). Pode-se ter também uma descrição mista, como em Tucídides a batalha à noite: com efeito, a noite é uma situação e a batalha é uma ação. Nós faremos a descrição de ações 
15. Hermógenes. Progymnasmata (Os Exercícios Preparatórios). In op. cit. (10-23), USP, 2002, p. 44.

16. Cf. Quintiliano, Instituição oratória, 7,7,10-25. "Laudantur vel vituperantur homines: ex tempore quod ante eos fuit (e genere (patria,maioribus, parentibus); ex tempore quod ipsi vixerunt(vivunt) speciatim: ex animo etc. ante eos fuit (e genere ( $p a-$ tria,maioribus, parentibus); ex tempore quod ipsi vixerunt(vivunt) speciatim: ex animo" etc. recorrendo aos acontecimentos que precederam, depois aos da própria ação, depois aos que se seguiram. Por exemplo: se fazemos a descrição de uma guerra, diremos inicialmente o que antecedeu a guerra, os movimentos de tropas, os gastos envolvidos, os temores, depois os combates, as feridas, as mortes, depois o troféu, depois os peãs (cantos) dos vencedores, as lágrimas dos outros, sua escravidão. Na descrição de lugares, de tempos ou de pessoas, teremos por matéria a presentação deles, mas também a beleza, a utilidade ou o caráter extraordinário. As virtudes da descrição são principalmente a clareza e a evidência: o discurso deve quase produzir a visão por meio da audição. É importante além disso que os elementos do discurso se modelem sobre as coisas: se a coisa é florida, o discurso o será também, se é seca, será do mesmo modo. ${ }^{15}$

1."A ekphrasis é um enunciado que apresenta em detalhe, como dizem os teóricos, que tem a vividez e que põe sob os olhos o que mostra”.

A matéria da ekphrasis é apresentação ou exposição do efeito de presença de algo ausente. Para dar conta dessa matéria, o autor aplica topoi epidíticos da heuresis, invenção, e palavras adequadas da léxis, elocução, conhecidos do destinatário. Os topoi são argumentos genéricos para expor ou descrever caracteres, paixões, atos, qualidades de deuses, homens, animais e coisas, como os topoi de pessoa - aspecto físico, origem, pátria, cidade, sexo, condição, idade, fortuna, língua, hábito, educação-aplicados segundo a oposição kalón/aiskhron, "belo/feio", simultaneamente agathon/kakon, "bom/mau". ${ }^{16}$ O regramento retórico das proporções da elocução aplicada a eles determina que o efeito amplificador e detalhador da ekphrasis seja avaliado pelo destinatário segundo duas funções simultâneas e complementares: uma função mimética e uma função judicativa. Mimeticamente, os efeitos põem em cena matérias ou coisas retóricas prescritas pelo costume da imitação de autoridades, como as coisas que Luciano aplica na ekphrasis dos centauros, as que Filóstrato lembra na descrição de Narciso, as que Aquiles Tácio narra no proêmio de Leucipa e Clitofonte. Judicativamente, a proporção aplicada ao efeito modela o ponto de vista do destinatário na própria variação elocutiva da descrição, compondo-o aristotelicamente numa posição interpretativa particular como theorós ou destinatário que contempla ou vê, intelectualmente, o que é mostrado ao seu ouvido. Assim, a ekphrasis encena topoi conhecidos e, simultaneamente, os critérios técnicos aplicados à variação elocutiva deles, efetuando o espanto, estranheza ou maravilha, causa do prazer.

2. "As virtudes da descrição são principalmente a clareza e a evidência: o discurso deve quase produzir a visão por meio da audição”.

Sobre a clareza, é útil reiterar que, por ser mimética, não é a clareza cartesiana unívoca, entendida como expressão de uma idéia pensada clara e distintamente, mas clareza elocutiva, escolhida em elencos de clarezas relacionais e aplicada conforme a verossimilhança e o decoro proporcionados aos topoi do gênero. Na ekphrasis, a clareza é obtida pelo uso de palavras próprias, nãobárbaras, escolhidas (delecta), metáforas (traslata), hipérboles (supralata) e sinônimos (duplicata). ${ }^{17}$ Evidentemente, quando a descrição é alegórica, o discurso 
17. Cícero. Partitiones oratoriae VI, 18, 22; De oratore III; Anônimo. Retórica para Herênio IV,19.

18. Marcos Martinho dos Santos. Lições sobre alegoria de gramáticos e retores gregos e latinos. Tese de doutorado (Mimeo). São Paulo: DLCVFFLCH-USP, 2002, p. 44.
19. O uso do discurso direto produz um "sujeito", no sentido linguístico e gramatical do termo; assim, quando a etopéia confere a palavra a uma coisa, tem-se a ficção de um personagem, ou prosopopéia, como ficção de um fantasma ou idolopéia. Como o autor do discurso não tem o recurso de notações descritivas exteriores para propor o estado de alma do personagem, os afetos saem imediatamente do discurso direto. $\mathrm{O}$ modo da enunciação da etopéia é o mesmo que se acha na tragédia ou na comédia. Cf. Patillon, Michel.

"Introduction". In Hermogène. L' Art Rhétorique. Ed. cit., p. 48.

20. Aphtonii Progymnasmata. Ed. H. Rabe, Leipzig, Teubner, 1926, cit. por Patillon, op. cit., p. 47. fica menos claro, mas também as alegorias têm graus prescritos de clarezas, que vão da alegoria totalmente aberta até o enigma cerrado. Os estóicos gregos falam dos oneiron theorematikoi, sonhos contemplativos. Referindo-se à luz da visão onírica, afirmam que as imagens do sonho são como ekphraseis (descrições) alegóricas, que põem frente aos olhos da mente coisas ausentes que brilham significando outras. Nos séculos IV e III a. C., Cleantes e Crisipo, que interpretaram alegoricamente os nomes de deuses e de atributos físicos de animais e deuses da poesia homérica, propuseram que a descrição de coisas físicas não-vergonhosas permite formular alegorias que fazem ver coisas ausentes moralmente vergonhosas. Marcos Martinho exemplifica com Calímaco, que alegoriza caso indecoroso, dizendo-o sem o dizer, ao usar de palavras próprias para descrever caso decoroso, "fogo", "cavalos nervosos" e "corrida", em "O fogo que acendeste anuncia muita chama, porém mantém os cavalos nervosos longe da corrida". ${ }^{18}$

Também é útil lembrar, quando se trata de ekphraseis que admitem o sentido alegórico, do proêmio de Iconologia (1593), em que Cesare Ripa define o conceito figurado nos emblemas do livro como "definição ilustrada". Em cada um deles, Ripa compõe a "alma" ou discurso recorrendo à notatio do Ad Herennium e outros retores latinos como técnica com que fixa perífrases dos caracteres das personificações ou alegorias de conceitos, como "prudência", "fraude", "fortaleza", "temperança", "primavera" etc. Para compor o "corpo" ou a imagem do emblema, Ripa recorre, entre outras autoridades, ao Physiognomonia, de Giovanni Della Porta, que, pela comparação dos traços do rosto humano com traços de animais, efetua deformações adequadas às paixões. Composto de alma e corpo, discurso e imagem, o emblema não propõe que poesia e pintura são a mesma coisa, mas evidencia a aplicação, em meios materiais diversos, dos mesmos procedimentos elocutivos que proporcionam ou desproporcionam epiditicamente a figuração efetuada.

Quanto à enargeia ou evidentia, é mais complicado. É preciso especificar o que é a opsis, a visão do "pôr sob os olhos" das definições de ekphrasis de Aélio Theon, Aftônio, Hermógenes, Filóstrato e Luciano, porque não é a visão realista ou naturalista das nossas histórias literárias e histórias da arte.

Aristóteles qualifica o efeito de enargeia- ao pé da letra, "vividez", como se vê no advérbio enargos ("vividamente") - como pro ommaton, "na frente do olho", propondo que as metáforas de ação impressionam mais, pois com elas o orador faz o evento narrado ocorrer como se os ouvintes o estivessem vendo. Na Retórica, dá como exemplo a fala de Isócrates que, tendo de dizer "A Grécia lamenta a morte dos soldados em Salamina", disse "A mãe Grécia chora seus filhos no túmulo de Salamina”. Os procedimentos técnicos para produzir enargeia são dramáticos, evidenciando-se como uma pragmática: uso de discurso direto ${ }^{19}$ e interpelação patética de personagens, como faz Filóstrato em "Os caçadores"; de apelo constante ao destinatário; de advérbios de lugar e de tempo referidos ao ato da enunciação; do presente pelo passado etc. O anônimo da Retórica a Herênio, Cícero e Quintiliano associam a evidentia assim produzida à persuasão dos três gêneros da oratória, definindo-a aristotelicamente como descriptio produtora de pathos que torna a causa debatida como que presente para os ouvintes, por isso persuasivamente eficaz (Inst. Orat. VI, 2,32; VIII, 3,67). Como diz Aftônio quando trata da etopéia, produzimos a ficção do éthos do locutor. ${ }^{20}$ O efeito patético é visio, "visão", correspondente ao grego phantasia: “(...) per quas (visiones) imagines rerum 
21. "Enargeia est imaginatio, quae actum incorporeis oculis subicit et fit modis tribus: persona, loco, tempore. Persona, cum absentem alloquimur quasi presentem. (...)Loco, cum eum, qui non est in conspectu nostro tanquam videntes demonstramus(...) Tempore, cum praeterito utimur quase praesenti(...).Schemata Dianoeas quae ad Rhetores Pertinent, Iullii Rufiniani. In Carolus Halm. Rhetores Latini Minores. Ex Codicibus Maximam Partem Primum Adhibitis. Leipzig (Teubner), 1868. Dubuque, Iowa-Reprint Library, sd, p. 71. USP, 2002, p. 44.

22. "Descriptio est oratio colligens et praesentans oculis quod demonstrat" Praeexercitamina Prisciani Grammatici Ex Hermogene Versa., In Rhetores Latini Minores. ed. cit., Liber 17, p. 558.

23. "Cf. Luisa López Grigera. História Textual: Textos Literarios (El Siglo de Oro). Mimeo. Ann Arbor-Michigan

University, 2004. "Ahora bien, de los tratados griegos post-aristotélicos conservados, el que ejerció mayor influencia fue el Perí Ideôn de Hermógenes. En él los tres géneros se convierten en siete formas o "ideas": claridad; amplitud; belleza o pulcritud; torvidad; estilo ético; verdad, y Deinotes o gravedad; ideas que a su vez se subdividen hasta llegar a veinte. Por su parte cada una de ellas se consideraba en ocho aspectos: pensamiento, tratamiento (figuras de pensamiento y estructura), dicción, (lengua adecuada al pensamiento). figuras de elocución; miembros e incisos; orden de las palabras y juntura; las cadencias, que contienen el numerus; $y$ finalmente el ritmo, que resulta de la unión de las cadencias y del orden de palabras: en fin, lo que la retórica latina llamaba compositio. De todas estas partes sólo la primera se refiere al tema; dos, la segunda y la cuarta, a las figuras; una, la tercera, a la selección de vocablos, tanto en sus aspectos fónicos como morfológicos y léxicos; las otras cuatro tienen que ver con la compositio, y constituyen una retórica sintáctica. Conviene recordar, para lo que vamos a estudiar, que la segunda idea, amplitud, que correspondía en cierto modo al estilo sublime o alto, se subdividía en seis estilos, tres de los cuales podían usar el período (brillantez, estilo florido y abundancia o "peribolé"), mientras que los otros tres usaban frases breves, e incisos (solemnidad, aspereza y vehemencia). Y el período se formaba por miembros paralelísticos más que por construcciones circulares”. Agradeço à autora a cópia do texto. absentium ita repraesentantur animo, ut eas cernere oculis ac praesentes habere videamur" (Quintiliano, 8,3,88). As técnicas dramáticas compõem a visão do destinatário segundo a perspectiva do ato da enunciação; a visão efetuada é, por isso, um ponto de vista a partir do qual o destinatário é contemporâneo dos aspectos da pintura suposta que "vê" per partes, como diz Quintiliano $(9,2,40)$, efetuando sua combinação e simultaneidade. A enargeia ou evidentia intensifica o efeito de clareza dos ornatos aplicados, tornando-os mais nítidos (nitidiora) (Quintiliano $8,3,61)$.

No texto Schemata Dianoeas, Júlio Rufiniano cita Quintiliano, definindo a enargeia da ekphrasis nos seguintes termos:

Enargeia é imaginação, que expõe o ato aos olhos incorpóreos e se faz de três modos: com pessoa, com lugar e com tempo. Com pessoa, quando chamamos o ausente como se estivesse presente (...). Com lugar, quando aquilo que não está na nossa visão demonstramos como se o víssemos (...) Com tempo, quando usamos o presente como passado. ${ }^{21}$

Também Prisciano, no livro 17 dos Praeexercitamina Prisciani Grammatici Ex Hermogene Versa, define descriptio "A descrição é enunciado que reúne e apresenta aos olhos o que demonstra". ${ }^{22}$

Em todas as definições de ekphrasis, o efeito de enargeia ou evidentia se entende como presença no aspecto. Para especificar o que seja a visão dessa "presença no aspecto" que entra pelos ouvidos, é útil observar que, repetindo Quintiliano e Aristóteles, Rufiniano fala de visão incorporeis oculis", visão "com olhos incorpóreos", que vêem a imaginatio. Sabe-se que, em grego, o termo theoria relaciona-se à contemplação ou visão em que se presenta o eidos da coisa vista intelectualmente. Um verbo cognato de eidos, eidenai, significa justamente ver o eidos, ou seja, saber. Relacionado a ele, o verbo theorein, "contemplar" e "teorizar", significa ver o eidos da coisa como alétheia, (des)velamento. O efeito da enargeia ou evidentia é o da imagem que põe sob os olhos incorporais da mente um topos retórico semelhante à opinião considerada verdadeira sobre o eidos. Descrito verbalmente, o topos também pode ser pintado ou esculpido, pois o fundamental nessa visão não é a reprodução de coisas empíricas, mas a imagem intelectualmente construída como (des)proporção do logos - razão e discurso - referido ao eidos. No ato da apreensão da ekphrasis, o juízo verifica se é semelhante às tópicas do costume antigo consideradas verdadeiras (endoxa), para julgar se o efeito de presença de coisas ausentes é verossímil. Aristotelicamente, a especificação da visão do juízo que vê com olhos incorpóreos o aspecto de uma pintura fictícia descrito por palavras determina que a ekphrasis seja um discurso que se dirige aos olhos do intelecto, que avalia duas coisas, como disse: se o preceito produtor do efeito está aplicado convenientemente e se o efeito se assemelha verossimilmente ao endoxon do topos imitado. Verificando, enfim, se há semelhança do discurso com aquilo que a teoria da coisa, a visão intelectual do eidos da coisa, determina seja considerado como a "opinião verdadeira" da maioria dos sábios. O que implica uma lógica da imagem formalizada como técnica retórica, não uma estética. ${ }^{23}$

Evidentemente, há outras interpretações. Por exemplo, platonicamente avaliado, o efeito da ekphrasis como descrição de obra de arte inexistente pode ser entendido como demiurgia, mas também como mímesis de mímesis de uma tekhné 
phantastiké que é "gráfica" - nos dois significados simultâneos de graphein, "escrever" e "pintar"- que deforma o eidos na aparência ilusória do efeito como eidolon, imagenzinha de imagem ou simulacro, indefinidamente.

3. "Na descrição de lugares, de tempos ou de pessoas, teremos por matéria a presentação deles, mas também a beleza, a utilidade ou o caráter extraordinário”.

Como disse, a presentação se faz com os topoi epidíticos doutrinados por Aristóteles, na Retórica, retomados no século I a.C. na Retórica a Herênio, sistematizados como ars laudandi et vituperandi na Instituição oratória, de Quintiliano, no séc. I d. C., e novamente expostos por Menandro, no séc. III d.C., na Repartição dos demonstrativos dedicada a Genétlio. No caso da ekphrasis como “descrição de pintura”, louvam-se o engenho, a perícia do pintor e, muitas vezes, seu caráter e atos. E sempre, como prescreve Hermógenes, a beleza, a utilidade e o caráter extraordinário da sua obra. Os preceitos para louvar o belo (kalón, honestum) também valem para vituperar o feio (aiskhron, turpe), em várias modalidades. Assim, o elogio de algo belo é elogio sério; a dominante do gênero epidítico, a ostentação de engenhosidade na invenção e perícia técnica da elocução, propicia modalidades cômicas em que o elogio adequado a coisas sérias pode ser aplicado jocosamente ou ironicamente a coisas indignas e baixas, feias, deformadas, misturadas e insignificantes. Menandro propõe quatro graus do elogio: $1^{\mathrm{o}} .0$ elogio de coisas inquestionavelmente dignas de elogio (endoxon), como a virtude. No caso das ekphraseis como "descrição de pintura", são endoxa a maravilha da idéia do pintor, a perspicácia e a versatilidade do seu engenho, a perícia técnica da sua arte na execução da obra; $2^{\circ}$. o elogio de males graves (ádoxon), por exemplo, a tirania; $3^{\circ}$.o elogio de coisas parcialmente dignas de elogio, parcialmente dignas de vituperação, com a defesa parcial das propriedades indignas (amphidoxon); $4^{\mathrm{o}} .0$ elogio paradoxal de coisas indignas de qualquer elogio- morte, escravidão, coisas insignificantes etc. (parádoxon). ${ }^{24}$

4. “... o discurso deve quase produzir a visão por meio da audição”.

Pressupondo e aplicando os quatro graus que especificam o louvor e a vituperação de virtudes e vícios, a ekphrasis é feita como perífrase ou hipotipose que efetua vividamente a presença da coisa, da pessoa ( como retrato, effictio), da ação, virtude ou vício, como se o ouvido da audiência quase os visse. Novamente, chamo a atenção para a destinação oral da ekphrasis: Hermógenes fala da audição como meio para a visão, pois prevê que a ekphrasis seja dramatizada oralmente, fazendo a audição do público - que tem a memória dos topoi e preceitos do exercíciocontemporânea das ações figuradas no enunciado pelo tempo presente dos verbos que efetuam a enargeia ou evidentia. Nesse sentido, a hipotipose é efetuada segundo uma proporção adequada da elocução aos topoi que modelam a matéria do discurso, mas também como proporção da hipócrisis, meletê, actio, pronunciação ou declamação do orador, que vai ao encontro do ouvido do destinatário sabendo que só fica persuadido com o efeito porque, ouvindo o encômio de coisas conhecidas ou prováveis, espera que seja engenhoso o modo de descrevê-las. Assim, quando diz que se deve fazer o encômio de ações e suas circunstâncias e o elogio de virtudes e seus graus, segundo o que é endoxon, mas também que o encômio pode ser feito 
ironicamente, como parádoxon encomion, quando se aplica a vícios e viciosos, Aristóteles pressupõe a audiência que domina os preceitos e está capacitada para distinguir a ironia não só nas palavras da elocução, mas também na pronunciação delas.

Nos dois subgêneros aristotélicos do cômico, guelóion, traduzido em latim por ridiculum, e psógos, traduzido por maledicentia, guelóion é deformação descrita para fazer o destinatário rir sem dor, pois efetua a feiúra própria dos vícios fracos caracterizados pela falta de virtude, como a covardia em relação à coragem. $\mathrm{O}$ psógos, vituperação ou maledicentia, aplica-se como deformação não-ridícula que causa horror e dor, pois produz feiúra própria dos vícios fortes, caracterizados pelo excesso, como a temeridade em relação à coragem. Emanuele Tesauro exemplifica a oposição em seu Tratatto dei Ridicoli, de Il Cannocchiale Aristotelico(1654), prescrevendo que, se a honra é virtude, menos vergonhoso é seu extremo vicioso, tirania, que seu outro extremo, servidão. A tirania é vício misturado com a força e a arrogância do coração, ao passo que a servidão é própria de um ânimo vil e impotente. Cômicas, tirania e servidão são deformações; mas o tirano deve ser descrito como deformidade horrorosa, que causa dor, enquanto para o servo é adequada a descrição como deformidade ridícula, que causa riso sem dor. Assim, aplica-se ao tirano o vitupério ádoxon, pois seu mal é evidentemente sempre grave, não admitindo jocosidade. Ao servo também é aplicável o parádoxon encomion, o elogio paradoxal, pois o ridículo admite a jocosidade e a ironia. Evidentemente, é possível tratar uma matéria ridícula de maneira horrorosa e vice-versa em formulações paródicas que pressupõem a memória do discurso citado.

Evidenciando a longa duração dos preceitos epidíticos, um texto anônimo, De attributis personis et negotiis Ex Ciceronis De Inventione Libro Primo, Sobre os atributos pessoais e negócios a partir do Livro Primeiro de De Inventione de Cícero, ${ }^{25}$ retoma Cícero e Quintiliano e reexpõe os lugares-comuns epidíticos atribuíveis a pessoas retratadas: nome, natureza, vida, fortuna, hábito, afetos, estudos, conselhos, feitos, palavras, casos. Prescreve que, se alguém se chama Calídio, a associação do nome com o fogo permite descrevê-lo como tipo temerário e inesperado, pois considera-se que os nomes são índices dos costumes. Como na sátira seiscentista atribuída a Gregório de Matos: "Nunca na fidalguia vi/ Mendonça sem ter Furtado". E, burlescamente, Frei Foderibus in Mulieribus. Também se considera a origem do tipo, pois a ascendência é indicativa do caráter. E o sexo, conforme seja homem ou mulher, ou seja homem e aja como mulher etc. E a nação, por exemplo se é grego ou bárbaro; ou a pátria, por exemplo se ateniense ou espartano; e a idade, se criança, adolescente, homem feito ou velho; ainda, o corpo, se forte ou fraco, se alto ou baixo, se formoso ou deformado, se veloz ou lento, etc. E também o vivido, por exemplo de que modo e por quem e com que meios foi ou não educado, e com quem vive, e como vive etc. E também a fortuna, se é livre ou escravo, rico ou pobre, aristocrata ou da plebe, feliz ou infeliz. E a língua. E os hábitos, as eleições, as paixões etc.

A ekphrasis feita como prosopografia ou retrato do aspecto físico aplica esses lugares compositivamente, como lemos no texto de Luciano, "Zêuxis ou Antíoco". Lembro rapidamente que o termo "retrato" é o particípio passado do verbo "retirar", significando "retirado" ou composição feita com particularidades abstraídas de pessoa por meio dos argumentos dos topoi. 

entre os versos 562 e 594 de seu Poetria Nova. A técnica prescreve a composição de retratos femininos segundo um eixo vertical imaginário que vai da cabeça aos pés, como se o olho do ouvinte, leitor ou espectador fosse recortando partes do corpo retratado sobre ele, detalhando cada secção horizontal com aspectos proporcionados ao decoro. Vinsauf prescreve que as partes sejam figuradas por palavras de efeitos visualizantes, como nomes de pedras preciosas, a cor branca e o brilho luminoso, pois os efeitos de luz tornam a proporção epidítica das formas evidente, bela e decorosa, compondo um todo harmônico. O preceito de composição do retrato feminino também pode ser aplicado por pintor, que deve dispor o personagem em pé, detalhando-lhe as partes do corpo, e cobri-las com roupas magníficas e jóias de ouro, que Vinsauf enumera.

Luisa López Grigera lembra que vários medievalistas, como o grande Edmond Faral, que em 1924 publicou Poetria Nova e outros textos de poética dos séculos XII e XIII em Les arts poétiques du XIIe et du XIIIe siècle, ficaram surpresos com que no século XIII aparecesse uma técnica de fazer retratos que, começando pelo cabelo, segue de forma descendente pelo rosto até os pés. Ela não aparece nos grandes textos latinos de retórica e poética - a Retórica para Herênio, os textos de Cícero, a Arte Poética, de Horácio, a Instituição oratória, de Quintiliano - que Poetria Nova conhece. A técnica parece ter sua origem nos progymnasmata gregos, em que é prescrita para descrever pessoas e compor retratos caracteriais, e também para inventar fábulas e amplificar a narração. Sobre ela, Aftônio diz algo: "Describentes vero personas, a summis ad ima usque ire oportebit, id est a capite ad pedes" (Descrevendo-se verdadeiramente pessoas, será oportuno ir do alto até embaixo, isto é, da cabeça aos pés). A hipótese que muitos medievalistas fizeram é que Geoffroi de Vinsauf teria tido conhecimento dos Progymnasmata de Aftônio, não se sabe se diretamente do texto grego. ${ }^{27}$

Quando expõem os modos de presentar pessoas, lembra Grigera, a Retórica a Herênio, Cícero e Quintiliano não prescrevem a técnica do retrato de Aftônio e Vinsauf, mas propõem dois modos: a notatio, pequena notação caracterizadora, como o termo lusca, "caolha", no poema de Marcial: "Quintus Thaidam amat/. Quam Thaidam? Thaidam luscam./ Thais unum oculum non habet; ille duos” ( Quinto ama Taís./ Qual Taís? Taís a caolha./ Taís não tem um olho; ele, os dois"). A notatio é uma perífrase que inclui a pessoa numa classe, "bom/belo" ou "mau/feio". Como a perífrase é de gênero demonstrativo, sua aplicação sempre pressupõe a questão: An honestum (turpe) sit? (É bom/belo(mau/feio)?). Além da notatio, o outro modo consiste em pintar o tipo por meio das onze circunstâncias de pessoa expostas por Quintiliano que referi. Assim, quando se descrevem o locus "natureza" e os bens (males) de fortuna da pessoa, por exemplo, podem ser mencionados os bens (males) do corpo, como "formosa" ou "caolha", sem que necessariamente a beleza ou o defeito indiciados na perífrase sejam descritos em seus aspectos particulares.

Grigera demonstra que Alfonso de Torres, retor espanhol do século XVI, coincide com Aftônio: “(...) si personam descripseris, a summis ad ima progrediaris, id est, a capite ad pedes", "se descreveres pessoa, do alto para baixo avançarás, isto é, da cabeça aos pés”. A partir dessa pequena prescrição, Torres propõe exercícios gramaticais e retóricos que dão conta de tipos variados de viciosos e vícios: ...personarum descriptio, quam Prosopographiam appellant, fit, cum 
28. Luisa López Grigera. Op. cit. pp.5-6.

29. Luisa López Grigera. Op. cit. pp. 78.

30. Como "centelha da consciência", a sindérese é a presença da Lei natural na mente, aconselhando o bem e vituperando o mal. No XVII, a noção relaciona-se com a doutrina do juízo e da prudência, fundamentando a solércia ou a sagacidade que especifica o tipo do discreto; é também a sindérese que evidencia, na forma exterior do decoro estilístico, as operações éticas do juízo, como circumscriptio. Cf. Santo Tomás de Aquino. Summa theologica, 20., I, 94,

31. Os Progymnasmata de Aftônio e os textos de outros retores gregos, como Hermógenes, Longino, Demétrio de Falero, Dionísio de Halicarnasso, circularam no Oriente, em Constantinopla, até o final do século XV. Eruditos gregos levaram esses textos para a Itália, onde foram publicados por Aldo Manúcio, em Veneza. No século XVI, a Companhia de Jesus passou a utilizálos nas aulas de retórica de seus colégios e, depois da edição do Ratio studiorum, em 1599, que sistematizou o ensino jesuítico, eles se tornaram textos básicos no ensino da composição. Como demonstra Luisa López Grigera no texto citado, nos séculos XVI e XVII, Aftônio e outros retores gregos voltaram a ser utilizados para ensinar alunos a compor descrições de cenas, objetos, pessoas, caracteres, paixões e aç̃es. Os modelos de ekphrasis fornecidos pelos textos gregos passaram a ser imitados, nesse tempo, por escritores de prosa e poesia, em adaptações que geralmente preenchem as secções do eixo vertical da técnica grega do retrato com as virtudes e vícios da preceptiva latina. Desses retratos que começam a descrição pela cabeça e a terminam pelos pés preenchendo as partes com vícios e virtudes, Luisa lembra o do licenciado Cabra, em El Buscón, e os de Maritornes e Clara Perlerina, no Quixote. depingius personam amantis, luxuriosi, avari, voracis, temulenti, somniculosi, invidi, sycophantae, parasiti, lenonis, gar[r]uli, aut gloriosi ostentatoris( ...) de personis, ut si dixeris: totus animo et corpore monstrum est: nam quamcunque vel animi vel corporis partem contempleris, monstrum reperies. Ingenium excute, prodigium invenies, mores expende, vitam scrutare, omnia monstrosa comperies: oculos, os, vultum... ${ }^{28}$ (... a descrição de pessoas, que chamam de Prosopografia, se faz com a pintura de pessoas enamoradas, luxuriosas, avarentas, glutonas, bêbadas, indolentes, invejosas, impostoras, parasitas, rufiãs, charlatãs e fanfarrãs (...) sobre pessoas, como se dissesses: pela alma e pelo corpo todo ele é um monstro: pois em qualquer parte que contemples, ou do ânimo ou do corpo, encontrarás um monstro. Exercita o engenho, encontrás um prodígio, expõe os costumes, observa a vida, todas as coisas monstruosas conhecerás: olhos, boca, rosto).

Assim Torres propõe que se descreva o criminoso: “(...) oculi truces et facies foeda cicatrice deformata... iam vero dentes putridi et graviter olens spiritus "(olhos ferozes e a cara toda horrível deformada por uma cicatriz... os dentes podres e o hálito infecto). Grigera cita um texto do século XVI dos Rhetoricae prolegomena, de Lorenzo Palmireno, que tem o título em latim e está em espanhol: Descriptio de formis foemina a divisione totius in partes (Descrição de mulher disforme pela divisão dela toda em partes): ${ }^{29}$

Tem a cabeça muito povoada de gado, os olhos tão grandes como castanhas, com ramela e empapuçados, sem cílios nas pálpebras, o nariz amassado, os beiços proeminentes, e podres os dentes e encavalados por haverem nascido cedo, o pescoço mais descarnado que bicho morto, os peitos estreitos e secos, as tetas como badalos, as espáduas como trilhos, o corpo ao contrário, corcovado e oitavado, crescido na cintura contrafeita de um lado, saliente o umbigo, os músculos empedrados, inchadas as pernas e nus os pés.

Para compor retratos cômicos, descrevem-se os tipos como mistos incongruentes, desproporcionados e confusos, uma vez que as paixões viciosas não têm unidade por serem extremadas por falta e por excesso de virtude, como Aristóteles afirma na Ética a Nicômaco. Assim como o pintor não erra quando faz um focinho torto sabendo que fere o decoro, também não erram os poetas que descrevem coisas fantásticas e inverossímeis que se tornam verossímeis e icásticas para efetuar a não-unidade do vício, o que ocorre quando as desproporções são observadas a partir de um ponto fixo. Nas letras ibéricas e italianas do século XVII, é calculado como unidade virtuosa de sindérese, ${ }^{30}$ a centelha da luz natural da Graça que aconselha o desenho interno do engenho de poetas e artífices. ${ }^{31}$

Aplicando a técnica do retrato exposta por Aftônio, Vinsauf, Torres e Palmireno, poetas do século XVII- Quevedo, Góngora, Lope de Vega, Caviedes, Sor Juana Inés de La Cruz, Gregório de Matos - compõem poemas cômicos produzindo a fusão das partes do retratado como se mimetizassem a indistinção pictórica dos grylloi cômicos de Bosch: fazem um esboço rápido e grosseiro, sem preocupação aparente com minúcias de desenho para ser visto de perto feito à ponta de pluma ou pincel, modelando-o como se utilizassem um carvão grosso ou uma broxa, empastando as cores e as linhas como um borrão na efetuação esquemática de caricaturas. Quando visto de perto pelas lentes de gêneros que prescrevem a descrição minuciosa e o exame atento de perto, o esboço se apresenta malfeito e 
32. Aristóteles, Rhet.,III, 12, 1414a 9-10 ("Quanto maior é a multidão, tanto mais de longe observa"). A expressão é de Emanuele Tesauro em "Il Giudicio". In I Panegirici sacri del molto reverendo padre Emanuele

Tesauro. Torino,1633. Cf. João Adolfo

Hansen. "O Juízo. Discurso

Acadêmico"(Trad.). In

Caniato,Benilde Justo e Miné,

Elza(Coord. e edição). Abrindo

Caminhos.Homenagem a Maria

Aparecida Santilli. São Paulo, Área de

Pós-Graduação de Estudos

Comparados de Literaturas de Língua

Portuguesa, 2002, pp. 165-172.

33. In Gregório de Matos e Guerra.

Obras Completas. Crônica do Viver

Baiano Seiscentista. Ed. James Amado

e Maria Conceição Paranhos. Salva-

dor, Janaína, 1968, 7 v. ("Vá de retra-

to" ( v. I, p.219-221); "Vá de aparelho"

(v. V, p. 1119-1121); "Eu vos retrato,

Gregório”(v. V,p.1308-309). borrado; mas, sendo poesia para ser apreciada à distância devido ao esquematismo dos traços, evidencia-se como verossimilhança e decoro próprios da recepção de tempo curto da praça em que é oralizada. "'Quanto maior populus sit”, diz o meu mestre, 'tanto longius spectat". ${ }^{22} \mathrm{O}$ destinatário do epidítico baixo não perde tempo com minúcias nem quer conceituações elaboradas. É exemplar a sátira atribuída a Gregório de Matos e Guerra, que a crítica brasileira, determinada por categorias românticas que ignoram o preceito retórico, afirma ser mal realizada e estilisticamente tosca, quando comparada com a lírica religiosa e amorosa atribuída ao poeta. Alguns poemas atribuídos ao poeta figuram o ato de escrever como ato de pintar, evidenciando o regramento retórico da proporção da elocução como ekphrasis que aplica a técnica de Aftônio e Vinsauf. Por exemplo, os que começam

$\begin{array}{ll}\text { Vá de retrato } & \text { Vá de aparelho } \\ \text { por consoantes, } & \text { vá de painel, } \\ \text { que eu sou Timantes } & \text { venha um pincel } \\ \text { de um nariz de tucano } & \text { retratarei a Chica } \\ \text { pés de pato. } & \text { e seu besbelho. }\end{array}$

Eu vos retrato, Gregório, desde a cabeça à tamanca cum pincel esfarrapado numa pobríssima tábua 33

5. “(...) se a coisa é florida, o discurso o será também, se é seca, será do mesmo modo".

O enunciado de Hermógenes doutrina a verossimilhança e o decoro da ekphrasis. Para comentar essa adequação mimética da emulação da pintura pelo discurso, proponho um análogo discursivo, os versos 361- 365 da Arte Poética, em que Horácio afirma que poesia é como pintura. Ut pictura poesis é, como se sabe, tópica de competição ou emulação entre as artes. Os versos põem em cena os preceitos que regulam a clareza, a verossimilhança e o decoro aplicados nessa emulação. É útil examiná-los, pois permitem especificar os modos como a ekphrasis constitui seus destinatários nas clarezas e evidências relacionais das descrições. Traduzo-os livremente:

(...) como a pintura, a poesia: haverá aquela (obra) que, se estiveres mais perto, te moverá mais, e outra, se estiveres mais longe; esta ama o obscuro, quer esta sob a luz ser vista, do juiz esta não teme o arguto juízo;

esta agradou uma vez, esta dez vezes repetida agradará.

Evidentemente, Horácio não diz que poesia é pintura ou que pintura é poesia, mas ut, "como", propondo na conjunção comparativa a homologia retórica dos procedimentos miméticos ordenadores dos efeitos em uma e outra. Assim, o ut que as relaciona parece indicar as modalidades técnicas do verossímil e do decoro necessários em cada gênero poético em termos de invenção, disposição e elocução, para que a obra particular cumpra as três funções retóricas gerais de ensinar (docere), agradar (delectare) e persuadir (movere). Os versos expõem 3 pares de oposições: a- distância: formulada em termos de perto/longe ( si propius stes- se estiveres mais perto/si longius abstes- se mais longe te afastares);b-claridade: formulada em termos de obscuridade/clareza (obscurum/sub luce); c-número: formulado em termos de uma vez/várias vezes (semel/ deciens repetita, uma vez/ 

andar rapezzando insieme

concetti spezzati e senza

dependenza e connessione fra loro; onde la sua narrazione ne riesce piè presto uma pittura intarsiata che colorita a olio; perchè essendo le tarsie um accozzamento di legnetti di diversi colori,com il quale non possono giammai accopiarsi e unirsi così dolcemente,che non restino $\mathrm{i}$ lor confini taglienti,e dalla diversità dei colori crudamente distinti,rendon per necessità le lor figure secche,crude, senza tondezza e rilievo;dove che nel colorito a olio sfumandosi dolcemente i confini si passa senza crudezza dall'uma all'altra tinta,onde la pittura riesce morbida,tonda, com forza,e com rilievo. Sfuma e tondeggia l' Ariosto, come quelli che è abbondantissimo di parole, frasi,locuzioni e concetti(...). Cf. Galileo

Galilei. Considerazione al

Tasso. In Opere

Letterarie.Con prefazione di

Riccardo Balsamo Crivelli e

note di vari. Milano, Casa

Editrice Sonzogno, p.25-26.

Wesley Trimpi propôs que, segundo Galileu, o poema de

Tasso parece uma Kunst-und-

Wunderkammer, uma saleta

de maravilhas repleta de singularidades triviais e isoladas, que não se encadeiam linearmente, mas devem ser vistas uma a uma acumuladas na obscuridade do recinto. Assim, se em Ariosto a poesia é produzida como galeria de pinturas que o olho percorre linearmente, vendo-as com clareza, de longe e de uma só vez, em Tasso cada minúcia brilha na obscuridade da câmara para ofuscar o olho, que perde o sentido do todo, enquanto se detém para observar, de perto e várias vezes, partes e minúcias das partes. Ao contrário de Galileu,

Emanuele Tesauro hipervaloriza Tasso, quando escreve agudamente que a estrela da agudeza engenhosa evita a claridade, onde perde a luz, exigindo a noite hermética dos conceitos enigmáticos para que seu brilho passe sob o arco do triunfo do cílio admirado do observador. Cf. Trimpi, Wesley- "The early metaphorical uses of SKIAGRAPHIA and SKENOGRAPHIA" in Traditio (Studies in ancient anda medieval history, thought and religion). New York, Fordham University Press, 1978, vol. XXXIV, pp.412-413.

dez vezes repetida). A categoria distância (vs.361-362) relaciona-se ao movere, legível no verbo indicador de pathos: te capiat magis ("te prenderá mais"); a categoria claridade relaciona-se ao docere (o que se evidencia no v. 364, que refere o juízo avaliador do efeito: iudicis argutum quae non formidat acumen ("esta não teme a agudeza arguta do juiz"); a categoria número (v. 365) articula o delectare, como se vê nos verbos indicativos de prazer, placuit, placebit (“agradou”,"agradará").

Como disse, as três categorias referem-se à verossimilhança e ao decoro: são aplicáveis como reguladores diferenciais do decoro interno e externo, podendo ser redistribuídas: perto/ clareza/ uma vez por oposição a longe/obscuridade/ várias vezes. Foram retomadas várias vezes, como acontece no texto em que Galileu as aplica como critérios avaliativos da qualidade poética da elocução de Orlando Furioso, de Ariosto, e de A Jerusalém Libertada, de Tasso. Propondo a pintura como termo de comparação, Galileu afirma que as transições bruscas de Tasso, seus ornatos agudamente herméticos e sua falta de coesão estilística são como uma pintura "társia" ou as tesserulae, pedrinhas de mosaico, metaforizadas por Cícero no Orador, 149, como lumina, " luzes". Quanto ao poema de Ariosto, afirma que seus versos dispõem os detalhes da ação narrada um ao lado do outro, como cores cujos limites se esfumam docemente em uma tela. Assim, o leitor o lê como se andasse por uma longa galeria alta e iluminada onde estão dispostas, em toda a extensão, obras de arte em espaços regulares, formando um todo claro e unificado. O poema de Tasso, ao contrário, é oblíquo e fantástico. ${ }^{34}$

Por outras palavras, a ekphrasis compete com a pintura não porque reproduza , como pintura, algo que o autor tenha visto na natureza ou numa obra de arte efetiva, mas porque mimetiza os modos técnicos, mimeticamente regrados, do "ver" da pintura, segundo o verossímil e o decoro do seu discurso. É o que vemos no texto "Zêuxis ou Antíoco", de Luciano:

Desse quadro Atenas hoje possui uma cópia de minuciosa exatidão (...) porque vi a imagem dessa imagem, vou por minha vez, com palavras, pintá-la o melhor que posso. Não sou, por Zeus, um grande perito na matéria, mas minha lembrança está fresca, pois eu a contemplei recentemente na casa de um pintor de Atenas; talvez minha viva admiração por essa obra-prima também contribua aqui para tornar minha descrição mais maravilhosa. ${ }^{35}$

Como disse, a imagem visualizante da pintura enunciada não preexiste ao ato do seu fingimento pelo narrador, que a inventa com tópicas que figuram situações, cenas, objetos, sentenças, tipos, corpos de tipos, caracteres, paixões, qualidades, quantidades, hábitos e relações das partes de corpos etc. Os argumentos são panegíricos, ou seja, argumentos ilustrados por exemplos e comparações que agradam ao público; em geral, são dispostos numa ordem que, simulando as partes do quadro para o olho do juízo do destinatário, deixam para o final da exposição o efeito de intensidade ou acmé. Novamente, pode-se exemplificar essa simulação comparativa de corpos com o texto de Luciano:

"Não é visto por inteiro, mas somente até a meia-altura de seu corpo de cavalo, erguendo com a mão direita um leãozinho até a parte inferior de sua cabeça como que se divertindo em assustar os filhinhos (...) Assim aparece o 
centauro; a fêmea é uma dessas éguas soberbas, como as cria sobretudo a Tessália, ainda ignorando o freio e a sela; sua metade superior é a de uma mulher perfeitamente bela, excetuadas suas orelhas, orelhas de sátiro. ${ }^{36}$

Como acontece na poesia, que faz a relação e a pintura de cada acontecimento, muitas vezes o discurso da ekphrasis, como aqui, é inventado como pintura de um ato por meio de "fatos" figurados no quadro inexistente, mas sem que o narrador recorra às razões deles. A descrição, feita "à maneira de" (= "à maneira das coisas feitas", os "fatos", e "à maneira da pintura", arte que mostra), é chamada de diatipose. ${ }^{37} \mathrm{Na}$ ekphrasis de Luciano, que transcrevo diante, a diatipose põe em cena, "à maneira de", uma circunstância particular de um fato- a reunião da família de centauros- sem explicar a razão da mesma. A diatipose também se aplica como prosopopéia, discurso direto de personagem que age e fala, caso da fala de Zêuxis com seu aprendiz, Mikkios, citada pelo narrador. Também é aplicada por meio de ações verossímeis realizadas por ocasião dos fatos, como a ação do centauro que sorri para os filhos enquanto segura o leãozinho. E, ainda, por meio de palavras que os personagens da pintura poderiam ter falado, também de modo verossímil. Sem deixar de ser provável, a diatipose pode figurar circunstâncias inauditas ou maravilhosas que habitualmente acompanham os "fatos", pois as encontra na verossimilhança epidítica prescrita para o gênero.

Simultaneamente, como disse, o narrador da ekphrasis dirige-se ao destinatário prescritivamente, fornecendo-lhe, na variação elocutiva do discurso, o modo como deve ouvir( ler) a descrição que efetua, ou seja, os preceitos da hipócrisis, meletê, actio, ação ou declamação na qual aciona memória dos topoi para compará-los com o efeito e avaliá-lo adequadamente. Categorias aplicadas, como a pureza, a clareza, a nitidez, o brilho, a veemência, produzem a enargeia ou evidentia, visualização imaginosa que intensifica a claridade do exposto, presentificando a pintura ausente. Com as palavras brilhantes, estimulando o páthos em si e nos ouvintes, o orador se exercita na ekphrasis produzindo phantasiai: ${ }^{8}$ a gênese das imagens fantásticas é seu engenho evidenciado no próprio exercício. Assim, compondo o destinatário numa posição de recepção efetuada como memória dos lugares de elocução epidítica do discurso, a ekphrasis põe em cena não só imagens fictícias da pintura, mas também um tipo específico de recepção constituída como apta para julgar o efeito segundo os preceitos de seu gênero e não de outro. Para ler a ekphrasis retoricamente, é preciso observar os preceitos de sua recepção fornecidos ao destinatário pelo narrador, uma vez que a instituição retórica não é uma "estética" e pressupõe que o juízo do destinatário refaz as operações da elocução e invenção normativamente, sendo juízo autoral.

Antes de ler o texto de Luciano, falo rapidamente da ekphrasis como descrição de pintura aplicada nos proêmios dos romances gregos como a matéria a ser desenvolvida pela narração. Por exemplo, em As Aventuras de Leucipa e Clitofonte, de Aquiles Tácio:

Chegando a esse lugar, após forte tempestade, ofereci sacrifícios à deusa dos fenícios; chamam-na Astarté os habitantes de Sídon. Passeando então pelo resto da cidade e olhando as oferendas, vejo uma pintura (graphé) votiva da terra e, ao mesmo tempo, do mar. A pintura era de Europa; o mar, o dos fenícios; a terra, a de Sídon. Na terra havia um prado e um grupo de 
39. Aquiles Tácio de Alexandria. Las Aventuras de Leucipa y Clitofonte. Introducción, versión y notas de Lourdes Rojas Álvarez. México, Universidad Nacional Autónoma de México, 1991,pp.1-2.
40. Cf. Jacyntho Lins Brandão . "O narrador no romance grego". In Ágora. Estudos Clássicos em Debate 1, 1999, pp. 31-56.

41. Jacyntho Lins Brandão. Op.cit. p. 39. jovenzinhas; no mar nadava um touro e sobre seu lombo estava sentada uma formosa jovem, navegando para Creta sobre o touro. ${ }^{39}$

Jacyntho Lins Brandão demonstra que a figuração de ekphraseis como matéria que a escrita do romance grego antigo finge imitar na composição de cenas, personagens e acontecimentos indica para o leitor a especularidade do texto. Assim, o narrador diz recordar-se de um quadro cuja pintura é mais bela que a natureza, propondo que sua narração os imita. No proêmio de Quéreas e Calírroe, escrito por Cáriton de Afrodísias no século I ou II d.C., o autor se apresenta: "Cáriton de Afrodísias, secretário de Atenágoras, o retor, uma paixão amorosa acontecida em Siracusa narrarei”. Jacyntho demonstra que imita o proêmio da História da Guerra do Peloponeso, de Tucídides: "Tucídides ateniense escreveu a guerra dos peloponésios e atenienses". Cáriton inventa um narrador que se autonomeia hypógrapheus, notário, escrivão, secretário, como garantia da isenção do que vai dizer; mas, como em seguida diz "narrarei", indica o lugar do seu ponto de vista: "Essas coisas sobre Calírroe escrevi” (égrapha). A mesma marca de $1^{\mathrm{a}}$. pessoa aparece no proêmio do romance de Longo, Dáfnis e Cloé, do II ou III d.C.:

Em Lesbo caçando, no bosque das Ninfas, um espetáculo vi, o mais belo de quantos vi: uma pintura de um quadro (eikónos graphein) uma história de amor (historian érotos). Belo também era o bosque, arborizado, florido, irrigado: uma fonte tudo alimentava, tanto as flores quanto as árvores. Mas a pintura (graphé) era mais encantadora, contendo tanto uma arte ímpar (techné perittéin) quanto um entrecho de amor Assim, muitos, mesmo dentre os estrangeiros por causa da fama ali vinham, como suplicantes das Ninfas, como espectadores do quadro (eíkónos theatai). (...) Muitas outras coisas-e todas de amor-vendo eu e admirando-as, tomou-me o desejo de escrever o que estava pintado (antigraphai ten graphein). E, procurando um intérprete do quadro (exegetés tes eikónos), quatro livros trabalhei, oferenda ao Amor, às Ninfas e a Pã, patrimônio encantador (ktéma tepnón) para todos os homens, o qual ao doente curará, ao triste consolará, ao que já amou fará recordar, ao que não amou instruirá. Pois ninguém jamais do Amor fugiu ou fugirá, enquanto beleza houver e olhos para ver. E a nós o deus permita sermos sensatos, ao escrevermos (graphéin) as histórias de outros. $4^{40}$

O proêmio já é uma narrativa em $1^{\mathrm{a}}$. pessoa que permite expor para o leitor as motivações do livro..$^{41}$ Novamente, a matéria que a narrativa afirma ser anterior, imitando-a de outro como pressuposto da memória do narrador, é uma pintura fictícia. Em decorrência, como acontece nas ekphraseis de Luciano e Filóstrato, a narrativa se faz como antigraphai ten graphein, "contraescrever o que estava pintado", sendo recebida como um "patrimônio" que, além de agradar, produz outros efeitos, como cura, consolo, recordação e ensino. Como disse, o narrador não relata os acontecimentos como se fossem eventos empíricos, mas como acontecimentos fictícios de uma pintura que só existe no seu discurso. Assim, como faz Filóstrato quando se autonomeia "hermeneuta", a narrativa sempre refere um intérprete (exégetes) da pintura, quase sempre o próprio narrador. O procedimento ficcional se torna mais complexo no caso do narrador das Histórias Verdadeiras, de Luciano, que escreve uma falsa fictio, ficção sobre o que não-é e não-ocorre, por 
isso improvável ou inverossímil, pois não há opinião semelhante ao não-ser. Fazendo seu narrador declarar que é mentira o que conta, Luciano divertia seu leitor antigo com o efeito, pois o leitor sabia que o "verdadeiro" da opinião sobre a descrição fantástica é não se deixar levar pela improbabilidade do efeito, mas avaliar o engenho e a arte dos preceitos críveis para narrar o incrível.

Quando Luciano descreve, no seu "Zêuxis ou Antíoco", o que afirma ser a obra mais famosa de Zêuxis, "A família dos Centauros", põe em cena os topoi e preceitos epidíticos que comentei, evidenciando que o quadro existe apenas na sua ekphrasis:

O ilustre Zêuxis,que foi mestre em sua arte, negligenciava ou tratava apenas muito raramente tópicos vulgarizados e demasiadamente conhecidos, heróis,deuses ou batalhas: incansavelmente dedicado à novidade, quando tinha concebido algum desenho extraordionário ou surpreendente, era nele que aplicava todos os meios de sua arte. Entre outras façanhas, um dia Zêuxis executou uma centauresa ladeada de seus filhotes, dois centauros gêmeos recém-nascidos. Desse quadro Atenas hoje possui uma cópia de minuciosa exatidão (...) porque vi a imagem dessa imagem, vou por minha vez, com palavras, pintá-la o melhor que posso. Não sou, por Zeus, um grande perito na matéria, mas minha lembrança está fresca, pois eu a contemplei recentemente na casa de um pintor de Atenas; talvez minha viva admiração por essa obra-prima também contribua aqui para tornar minha descrição mais maravilhosa. Sobre uma relva alta, destaca-se a própria centauresa; todo o seu corpo de cavalo está deitado, os pés traseiros estendidos, a parte humana ligeiramente alçada sobre um dos cotovelos. Os pés da frente não estão aumentados, como os de um animal, sobre o flanco: um deles se arredonda, o casco se dobra, como que para flexionar o joelho; o outro,ao contrário, endireita-se e se apóia no chão, como os cascos dos cavalos que se esforçam para se levantar.Os dois pequenos, um é carregado nos seus braços e nutrido como uma criança no seu seio de mulher; o outro,como um potro, chupa sua mama de égua. No alto, como uma sentinela, está um Centauro, evidentemente o esposo dessa que amamenta de uma parte e doutra cada filhote; ele inclina-se rindo. Não é visto por inteiro, mas somente até a meiaaltura de seu corpo de cavalo, erguendo com a mão direita um leãozinho até a parte inferior de sua cabeça como que se divertindo em assustar os filhinhos (...) Assim aparece o centauro; a fêmea é uma dessas éguas soberbas,como as cria sobretudo a Tessália, ainda ignorando o freio e a sela; sua metade superior é a de uma mulher perfeitamente bela, excetuadas suas orelhas, orelhas de sátiro. No entanto, a mistura e a fusão dos dois corpos, o ponto onde a natureza humana se une e se junta à outra é tratado com tal delicadeza, tal fineza, tão grande arte na transição que o olho passa de uma a outra insensivelmente. Nos pequenos, a fisionomia é selvagem sem cessar de ser jovem, feroz sem cessar de ser terna, e, o que particularmente me maravilhou, é seu olhar bem infantil virado para o leãozinho, sem que nenhum deles abandone a mama do corpo da mãe que os alimenta. Que vale o conjunto da obra-prima segundo os diversos pontos de vista que escapam em parte à nossa inteligência figurando o essencial da arte, quero dizer, a correção do desenho, o jogo impecável e a feliz combinação das cores, a justeza das sombras, as proporções verdadeiras, a relação exata e a harmonia 
42. Luciano de Samósata. Trad. de A.Reinach, La Peinture Ancienne, 1921; Macula, 1985, 3-8:3. das partes com o todo? Cabe aos filhos de pintores o louvor disso tudo : é seu ofício reconhecer-se nessas coisas. Por mim, o que mais admirei em Zêuxis é ter aplicado os talentos variados de seu engenho numa única e mesma matéria. Assim o macho é absolutamente feroz e verdadeiramente selvagem, a crina arrogante, o corpo peludo não só em sua parte animal mas também na humana, as espáduas muito alargadas, o olhar, ainda que ria, de besta selvagem, em suma, feito para a montanha e de humor difícil. $4^{2}$

O que o narrador de Luciano diz sobre Zêuxis e a pintura é, especularmente, o que o autor Luciano faz quando escreve a ekphrasis em que o narrador aparece. Por outras palavras, o ato da enunciação do narrador do texto é homólogo dos atos da pintura de Zêuxis figurados no enunciado. Assim, quando o narrador louva Zêuxis, extraindo o louvor da estranheza da matéria do quadro fictício e da engenhosidade e da perícia técnica do pintor, também louva a estranheza, a engenhosidade e a perícia do próprio discurso. Particulariza ficcionalmente as partes da tela fictícia, amplificando-as e encarecendo-as, também particularizando e encarecendo ficcionalmente, com isso, as partes do próprio discurso. E também as compara, fazendo outras amplificações, também comparando, com isso, partes do próprio discurso em outras descrições. Assim, começa por constituir o ponto de vista do destinatário e, para isso, aplica topos de modéstia, afirmando que não é perito, para imediatamente dizer que escreve movido pelo entusiasmo causado pelo espanto da visão do quadro que afirma ter visto. A admiração alegada põe em cena o caráter extraordinário da obra, como prescreve Hermógenes, evidenciando para o destinatário que à admiração pressuposta na enunciação corresponde a maravilha epidítica da sua ekphrasis. Em seguida, situando a centauresa e os filhos num topos bucólico, aplica tópicas epidíticas de "bens da natureza", fazendo a descrição do aspecto físico dos monstros. Os centauros são caracterizados por adynata que compõem paixões correspondentes à sua natureza mista: "feroz sem cessar de ser terna”, "o olhar, ainda que ria, de besta selvagem". E isso porque, como lembra Castelvetro nos seus comentários da Poética aristotélica, o louvor e a vituperação pressupõem que o fisicamente bem formado, kalon/pulchrum/belo, e o fisicamente mal formado, aiskhron/turpe/feio, aparecem ao ouvido e ao olho como evidência sensível da proporção racional da virtude e da desproporção irracional do vício inteligíveis pelo olho interior da mente. Por outras palavras, o aspecto físico dos centauros metaforiza ou alegoriza a natureza de seus afetos, quando a imagem se oferece ao juízo do ouvinte ou leitor: "feitos para a montanha e de humor difícil". Ao mesmo tempo, o narrador chama a atenção do destinatário para as sutilezas de Zêuxis na figuração da rudeza: "No entanto, a mistura e a fusão dos dois corpos, o ponto onde a natureza humana se une e se junta à outra é tratado com tal delicadeza, tal fineza, tão grande arte na transição que o olho passa de uma a outra insensivelmente".

Insistindo no artifício, lamenta adiante que seu ouvinte e leitor tendam a valorizar apenas a estranheza da matéria descrita em sua ekphrasis, afirmando que desejou aliar à estranheza o respeito pelas autoridades antigas. A obra não deve ser valorizada apenas pela maravilha, mas principalmente porque também imita os preceitos antigos de autoridades: “(...) essa feliz escolha de frases das quais os autores antigos nos deixaram o modelo, essa vivacidade de pensamentos, essa fineza 
43. Luciano de Samósata. Traduction d'Eugène Talbot, Paris, Hachette, 1882. de imaginação, essa graça ática, essa harmonia, a arte, enfim, que resulta de todas essas qualidades".

Por isso, referindo-se à pintura, os enunciados mimetizam "o essencial da arte" da ekphrasis, fornecendo ao destinatário o preceito que deve aplicar para julgá-la, ou seja, "a correção do desenho, o jogo impecável e a feliz combinação das cores, a justeza das sombras, as proporções verdadeiras, a relação exata e a harmonia das partes com o todo". Luciano também escreve que alguns dos espectadores gritaram espantados, quando viram o quadro, e que Zêuxis já esperava que os enchesse de entusiasmo, pois não conheciam a idéia e louvariam precisamente a sua singularidade. Ao ver que é só a singularidade da tópica o que os entusiasma, pois se esquecem da execução e tratam como coisa acessória a arte de cada detalhe, Zêuxis fala ao seu aprendiz:: «Vamos embora, Mikkion, embale o quadro para levá-lo para casa; essa gente só louva a lama do ofício e não se importa com a essência da beleza e o fundamento da arte; o talento da execução desaparece frente ao imprevisto da matéria”. Novamente, o que Zêuxis diz sobre a pintura e o público vale especularmente para a ekphrasis e seu destinatário: o ouvinte e o leitor devem ser capazes de ocupar a posição do narrador absolutamente ciente dos preceitos que aplica, para poderem avaliar o artifício aplicado. Quem apenas valoriza a estranheza do efeito demonstra ignorar que Luciano compõe a ekphrasis com preceitos homólogos dos preceitos do quadro inexistente, competindo discursivamente com o pintor.

Por outras palavras, para ler ekphraseis é fundamental observar o topos da emulação das artes: Luciano compõe ekphraseis que descrevem o talento dos pintores Apeles e Zêuxis para evidenciar que seu engenho é capaz de competir discursivamente com eles. Mais que descrições de quadros, valem como argumentos que defendem sua eloqüência oratória. A exemplaridade da obra de Zêuxis só se torna visível por meio da sua ekphrasis que, fingindo o reconhecimento da sua qualidade, demonstra ser capaz de avaliá-la com qualidade poética idêntica ou superior. Assim, o louvor do efeito maravilhoso e da perfeição técnica da pintura dos centauros é circular: o discurso louva a imagem fictícia dos seres mistos pintados por Zêuxis para louvar-se a si mesmo como mescla estilística que os efetua ficcionalmente. A emulação (zelos) da pintura inexistente que o narrador de Luciano descreve ficcionalmente, declarando tê-la visto, sobredetermina a ekphrasis como ficção da ficção: “(...) porque vi a imagem dessa imagem, vou por minha vez, com palavras, pintá-la o melhor que posso”.

Quando lemos a ekphrasis 23, dos Eikones, de Filóstrato, encontramos a mesma contrafação em que a ficcionalização da ficção da pintura é disposta como se o destinatário a estivesse vendo da perspectiva do sujeito de enunciação segundo vários espelhamentos que evidenciam o artifício enquanto o dissimulam na enargeia do efeito de presença:

Esta fonte reproduz os traços de Narciso,como a pintura reproduz a fonte, o próprio Narciso e sua imagem. O jovem que volta da caça está em pé perto da fonte suspirando por si mesmo fascinado da própria beleza, iluminando a água, como vês, com sua graça radiosa (... ) fiel à verdade, a pintura nos mostra a gota de orvalho suspensa nas pétalas; uma abelha pousa na flor, eu não saberia dizer se está enganada pela pintura ou se não somos nós que nos enganamos crendo que ela existe realmente. Mas, seja, erramos. 
44. Filóstrato de Lemnos. Eikones. Trad. A. Bougot. Paris, Renouart, 1881, Livro I, 23.
Quanto a ti, jovem, não é uma pintura o que causa tua ilusão, não são as cores nem uma cire enganadora que te mantêm preso ; não vês que a água te reproduz tal como tu te contemplas ; não te apercebes do artifício dessa fonte (...)Mas Narciso não nos ouve: a água cativou seus olhos e ouvidos. Digamos, pelo menos, como o pintor o figurou (...) os dois Narcisos são semelhantes, brilham com a mesma beleza; a única diferença entre eles é que um se destaca contra um fundo de céu e o outro é visto como mergulhado na água; o jovem se mantém imóvel sobre a água que está imóvel ou, antes, que o contempla fixamente,como que tomada pela sua beleza. 44

Não há espaço para mais exemplos e termino, sem acabar, lembrando ao leitor o conto de Borges sobre os geógrafos do rei. 